\title{
PENGARUH PENYARUNGAN DENGAN BERBAGAI KETEBALAN PLASTIK DAN DIAMETER BUAH TERHADAP SERANGAN PENGGEREK BUAH KAKAO Conopomorha cramerella (Snellen) (LEPIDOPTERA : GRACILLARIDAE)
}

\section{NI MADE DELLY RESIANI}

\begin{abstract}
This research is aimed to find out the preference of cocoa pod borer to diameter, biophysical, and biochemistry cocoa pod; percentage of infested pods, percentage of seed damaged, and percentage of yield lost. In addition, this research is also aimed to assess the effect of plastic thikness to cacao pod rot disesase, the effect of shething to black ant and mealy bug populations on pods.

This research was conducted at Selemadeg District, Tabanan Regency from October 2009 until January 2010. The field trial was arranged into randomized complete block design (RCBD) by 15 treatments were sheathing with various thickness of plastics $\left(\mathrm{S}_{0^{-}} \mathrm{S}_{4}\right)$ and cocoa pod diameters $\left(\mathrm{B}_{1}-\mathrm{B}_{3}\right)$.

The results indicated that, based on percentage of infested pod, cocoa pod borer was prefer the fruit with diameter $>4.5-7.5 \mathrm{~cm}$. This condition may be contarast, the smallest pod size $(3,5-4,5 \mathrm{~cm})$ was the healthiest pod, even though it contains more nutritionally compound. The smaller pod rot disease in red and green types. Sheathing by plastic of $>$ $0.02 \mathrm{~mm}$ thick in medium size of pods was the most effective to prevent cocoa pod borer infestation. Sheathing with plastic was not affecting the population of both black ants and mealy bugs. Based on these results, it can be suggested that sheathing with plastic of $>0.02$ $\mathrm{mm}$ thick on medium size of pod is promising control measure to prevent yield lost caused by cocoa pod borer and cocoa pot rot disease.
\end{abstract}

Keyword: Sheathing, plastic thickness, pod diameter, cocoa pod borer Conopomorpha cramerella, (Snellen), cocoa.

\section{Pendahuluan}

Kakao merupakan salah satu komoditas unggulan provinsi Bali dari sub sektor perkebunan. Kakao Bali sangat spesifik sehingga sangat diminati oleh konsumen kakao nasional maupun dunia.

Produksi biji kakao Bali dari tahun 2003 terus meningkat sampai tahun 2005 yang didukung oleh meningkatnya jumlah tanaman produktif, akan tetapi laju produktivitasnya mengalami penurunan di beberapa Kabupaten sebesar $6 \%$ pada tahun 2005 dan 42,71\% pada tahun 2006. Penyebab utama menurunnya produksi biji kakao tersebut karena adanya serangan organisme pengganggu tanaman 
Ni Made: Pengaruh penyarungan dengan berbagai ketebalan plastik dan diameter buah terhadap serangan penggerek buah kakao

yang didukung oleh keadaan cuaca yang tida menentu.

Hama penggerek buah kakao (PBK) yang dikenal dengan Conopomorpha cramella (Snellen) (Lepidoptera: Gracillaridae) merupakan penyebab utama menurunnya produksi biji kakao tersebut. Serangan hama tersebut dapat menurunkan produksi sampai $82,2 \%$, karena sifat penyebarannya cepat dan sulit dikendalikan (Wardojo, 1980).

Pengendalian penggerek buah kakao yang dilakukan petani sampai saat ini masih mengandalkan penggunaan insektisida sintetis. Cara tersebut dipilih karena insektisida sintetis yang berlebihan secara terus menerus dan tidak terkontrol dapat menimbulkan akibat negatif terhadap lingkungan seperti adanya residu dalam tanah, air udara menyebabkan kekebalan (resistensi), ledakan (resurjensi) hama, timbulnya hama sekunder, terbunuhnya musuh alami dan makhluk lain yang bukan sasaran serta menyebabkan berbagai penyakit dan kematian pada manusia (Oka, 1995). Karena itu diperlukan upaya penanganan alternatif yang ramah lingkungan.

Alternatif pengendalian yang juga dianggap efektif untuk melindungi buah dari serangan penggerek buah kakao adalah dengan melakukan penyarungan buah dengan kantung plastik (Sudarmadji dkk, 1990; Sulistyowati, 2003).

Penyarungan buah pada prinsipnya bertujuan menghalangi imago penggerek buah kakao meletakan telur pada permuakaan buah. Wardojo (1981) menyatakan bahwa perlakuan penyarungan pada buah kakao menghasilkan $80 \%$ buah sehat dan $20 \%$ buah terserang, sedangkan tanpa penyarungan buah yang terserang mencapai 100\%. Sulistyowati (2003) menyatakan bahwa efektivitas penyarungan buah dapat mencapai 95 $100 \%$, namun demikian penyarungan buah dengan kantung plastik tersebut menimbulkan masalah baru yaitu adanya efek lain berupa serangan penyakit busuk buah. Serangan busuk buah tersebut diduga akibat pengaruh ketebalan plastik sarung. Petani umumnya menggunakan plastik yang tipis $(0,02 \mathrm{~mm})$ untuk menyarungi buah kakao mereka. Plastik yang tipis tersebut mudah menempel pada keseluruhan permukaan buah, sehingga uap air yang timbul dalam buah memungkinkan kondisi baik bagi perkecembahan spora masuk ke dalam 
Ni Made: Pengaruh penyarungan dengan berbagai ketebalan plastik dan diameter buah terhadap serangan penggerek buah kakao

sarung. Kondisi seperti itu diduga memicu proses inkubasi jamur yang menular ke dalam buah.

Penyarungan buah telah dikenal di kalangan petani, namun informasi mengenai ketebalan plastik sarung yang dipasangkan pada diameter buah yang tepat belum diketahui dengan pasti oleh sebagian besar petani. Informasih tersebut semestinya diketahui oleh petani untuk menghindari bah dari serangan penggerek buah kakao dan infeksi penyakit busuk buah kakao.

Berdasarkan hal tersebut, maka perlu dilakukan penelitian penyarungan buah dengan menggunakan ukuran ketebalan plastik sebagai bahan sarung dan ketepatan diameter buah yang akan disarungi, sehingga perubahan temperatur dalam buah tidak menguntungkan bagi pertumbuhan jamur busuk buah kakao dan tingkat serangan penggerek buah kakao dapat ditekan.

METODE PENELITIAN

\section{Rancangan Percobaan}

Rancangan yang digunakan dalam percobaan ini adalah Rancangan Acak Kelompok (RAK) yang terdiri dari 15 perlakuan yakni ketebalan plastik (S) dan diameter buah (B) yang diulang sebanyak
23 kali dalam kelompok tanaman berbuah merah dan 23 kali dalam kelompok tanaman berbuah hijau.

Perlakuan tersebut adalah : $\mathrm{S}_{0} \mathrm{~B}_{1}, \mathrm{~S}_{1}$ $B_{1}, S_{2} B_{1}, S_{3} B_{1}, S_{4} B_{1}, S_{0} B_{2}, S_{1} B_{2}, S_{2}$ $B_{2}, S_{3} B_{2}, S_{4} B_{2}, S_{0} B_{3}, S_{1} B_{3}, S_{2} B_{3}, S_{3} B_{3}$ dan $S_{4} \quad B_{3}$. Perlakuan $S 0=$ Tanpa penyarungan, $\mathrm{S} 1=$ Penyarungan tebal plastik $0,02 \mathrm{~mm}, \mathrm{~S} 2=$ Penyarungan tebal plastik $0,03 \mathrm{~mm}, \mathrm{~S} 3=$ Penyarungan tebal plastik $0,04 \mathrm{~mm}, \mathrm{~S} 4=$ Penayarungan tebal plastik $0,05 \mathrm{~mm}, \mathrm{~B} 1=$ diameter buah 3,5-4,5 cm, B2 = diameter buah > $4,5-6,0 \mathrm{~cm}, \mathrm{~B} 3=$ diameter buah $>6,0-$ $7,0 \mathrm{~cm}$.

\section{Lokasi dan Waktu Percobaan}

Percobaan dilaksanakan di Subak Abian Palasari, Dusun, Desa, dan kecamatan Selemedeg, Kabupaten Tabanan. Percobaan dimulai dari bulan Oktober 2009 sampai dengan bulan Januari 2010.

\section{Alat dan Bahan}

Alat yang digunakan dalam percobann ini meliputi : kantung plastik transparan cap Jet No 264872 berkuran lebar $20 \mathrm{~cm}$, panjang $30 \mathrm{~cm}$ dengan tebal $0,02,0,03,0,04$, dan $0,05 \mathrm{~mm}$ sebagai sarung, karet gelang sebagai pengikat sarung, alat pemasang sarung yang 
Ni Made: Pengaruh penyarungan dengan berbagai ketebalan plastik dan diameter buah terhadap serangan penggerek buah kakao

terbuat dari pipa PVC panjang $150 \mathrm{~cm}$ dengan ukuran $1,5,2$, dan 2,5 dim, sulih bambu raut panjang $125 \mathrm{~cm}$ untuk menukik, karet gelang pengikat plastik pada buah, label pengamatan, hand counter, lup, pisau, gunting pangkas, penggaris, timbangan, altimeter, thermohygrometer, jangka sorong, kantung plastik besar tempat buah panen, lembar pengamatan, kamera, buku catatan, dan alat pencatat, sedangkan bahan yang digunakan dalam percobaan ini adalah buah kakao.

\section{Pelaksanaan Percobaan}

Percobaan pengaruh penyarungan dengan ukuran ketebalan plastik dan diameter buah terhadap serangan penggerek buah kakao dilaksanakan di kebun kepemilikkan petani dengan luas kebun sekitar 1 hektar. Tanaman kakao yang dipakai dalam percobaan ini berumur delapan tahun, jenis kakao lindak (warna merah dan hijau) dengan jarak tanam $5 \mathrm{~m}$ x $5 \mathrm{~m}$. perlakuan sebanyak 15 unit perlakuan ditempatkan dalam satu ulangan. Satu ulangan terdiri dari satu pohon kakao. Penentuan ulangan dalam petak percobaan dilakukan secara purposive sampling (Tanaman sengaja dipilih sesuai kriteria perlakuan).
Perlakuan penyarungan dilakukan pada awal percobaan sesuai dengan ukuran diameter buah. Setiap sampel diberi label dan pengamatan dilakukan setelah perlakuan sampai panen.

\section{Variabel Pengamatan}

Variabel yang diamati dalam percobaan ini adalah : preferensi penggerek buah kakao, sifat biofisik dan kandungan biokimia buah, persentase biji terserang penggerek buah kakao (\%), persentase kehilangan hasil per buah (\%), kehidupan semut hitam dan kutu putih pada buah kakao, persentase serangan penyakit busuk buah kakao (Phytopthora palmivora)

\section{Analisis Data}

Data dianalisis secara statistika dengan menggunakan analisis varian. Jika uji $\mathrm{F}$ menunjukkan perlakuan berpengaruh nyata terhadap variabel yang diamati, maka untuk membandingkan nilai rata-rata antar perlakuan digunakan uji beda rata-rata DMRT (Duncan's Multiple Range Test) taraf $5 \%$ (Gomez dan Gomez, 1995)

\section{PEMBAHASAN}

Penyarungan dengan berbagai ketebalan plastik dan diameter buah memberikan pengaruh nyata terhadap 
Ni Made: Pengaruh penyarungan dengan berbagai ketebalan plastik dan diameter buah terhadap serangan penggerek buah kakao

penurunan serangan penggerek buah kakao. Dilihat dari persentase buah terserang, penggerek buah kakao lebih menyukai buah yang berdiameter $>4,5-$ $6,0 \mathrm{~cm}$, tetapi tidak berbeda nyata dengan buah yang berdiameter $>6,0-7,5 \mathrm{~cm}$, baik pada buah hijau maupun merah. Tingginya persentase buah terserang pada buah yang berdiameter $>4,5-6,0 \mathrm{~cm}$ disuga berkaitan dengan preferensi atau tingkat kesukaan penggerek buah kakao terhadap buah. Preferensi penggerek buah kakao terhadap buah yang berdiameter > 4,5 - 6,0 cm, didukung oleh keadaan biofisik buah dan kandungan biokimia buah terhadap kelangsungan hidup penggerek buah kakao. Biofisik buah yang berdiameter $>4,5-6,0 \mathrm{~cm}$, baik pada buah kakao berwarna merah maupun hijau memiliki alur buah yang dalam dengan ketebalan kulit buah yang tipis sangat mendukung penggerek buah kakao dalam peletakan telur dan telur dapat menempel lebih kuat sampai menetas menjadi larva. Menurut Hwang dan Hsieh (1989) buah yang beralur dalam dan buah yang berumur kurang dari 7 minggu sebelum matang tersebut selain alurnya dalam juga mempunyai nutrisi terutama protein lebih tinggi dibandingkan buah yang lebih tua. Larva penggerek buah kakao yang baru menetas memerlukan nutrisi dan energi untuk pembentukan jaringan-jaringan dan perkembangan hidup selanjutnya. Pada buah yang berdiameter $>4,5-6,0 \mathrm{~cm}$ mempunyai kandungan protein dan gula yang cukup bagi larva penggerek buah kakao. Azhar dan Long (1996) selain kandungan nutrisinya lebih tinggi juga kandungan non nutrisi (tanin dan fenol) lebih rendah dibandingkan buah muda. Hasil penelitian tersebut diperkuat oleh hasil penelitian yang telah dilakukan oleh Wardojo (1981), Sjafruddin dkk (2006), dan Supartha dkk (2007;2008b).

Buah yang berdiameter $>6,0-7,5 \mathrm{~cm}$ persentase serangannya tidak berbeda nyata dengan buah yang berdiameter > 4,5 - 6,0 cm. Kejadian itu kemungkinan terjadi karena imago penggerek buah kakao telah mengalami perubahan perilaku bertelur atau buah sudah terserang sebelunya. Kondisi biofisik buah yang berdiameter $>6,0-7,5 \mathrm{~cm}$ tampak alur buahnya dangkal dengan kulit buah yang tebal, namun kondisi biokimia buah (non nutrisi) mendukung. Wardojo (1981) menyatakan bahwa alur buah yang dangkal menyebabkan imago 
Ni Made: Pengaruh penyarungan dengan berbagai ketebalan plastik dan diameter buah terhadap serangan penggerek buah kakao

penggerek buah kakao susah meletakan telurnya karena mudah tergelincir, kulit buahnya keras dan tebal sehingga menyulitkan penusukan ovipositornya pada buah. Supartha dkk (2008a) menyatakan bahwa kulit buah yang lebih tebal tampak lebih tahan terhadap penggerek buah kakao. Keadaan itu disebabkan oleh tanaman yang memiliki kulit buah yang licin, alur buah dangkal dengan rata-rata kulit buah yang tebal secara genetis tidak disukai oleh hama penggerek buah kakao karena susah dihinggapi dan ditempati oleh hama penggerek buah kakao untuk meletakan telur. Telur yang diletakan pada permukaan buah lebih mudah jatuh, sedangkan buah beralur dalam memudahkan imago hinggap meletakkan telurnya (Asrul, 2004). Anshary (2002) menyatakan bahwa karakter fisik buah kakao yang keras dan tebal menyebabkan larva mengalami hambatan dalam melakukan penetrasi pada saat masuk kedalam buah dan keluar untuk membentuk pupa.

Berbeda dengan buah yang berdiameter 3,5-4,5 $\mathrm{cm}$, persentase serangan penggerek buah kakao tampak paling rendah. Biofisik buah pada buah yang berdiameter $3,5-4,5 \mathrm{~cm}$, walaupun mempunyai alur buah yang dalam dan ketebalan kulit buah yang tipis, namun sifat biokimia terutama kandungan senyawa non nutrisi (tanin dan fenol) lebih tinggi dibandingkan dengan diameter buah lainnya. Chiang dan Norris (1983) menyatakan bahwa senyawa tanin dan fenol termasuk senyawa penghalang dan penolak bagi imago yang dapat mempengaruhi palatibilitas buah dan perilaku penelusuran serangga. Senyawa tersebut dapat menjadi penolak imago dan penghambat pertumbuhan serangga pradewasa akibat kekurangan protein dan terhambatnya enzim-enzim, sehingga secara tidak langsung berperan sebagai racun bagi serangga tersebut. Senyawa tanin juga mempunyai kemampuan mengikat protein membentuk kompleks zat penghambat pencernaan yang tidak larut dan berfungsi sebagai penghambat makan (feeding suppressant), (Smith, 1989), selain itu tanin juga dapat mengikat protein sehingga protein tidak dapat terurai oleh enzim-enzim di dalam saluran pencernaan serangga pemakannya (larva penggerek buah kakao) (Vickery dan Vickery, 1981). Senyawa tanin dan fenol juga dapat berfungsi sebagai 
Ni Made: Pengaruh penyarungan dengan berbagai ketebalan plastik dan diameter buah terhadap serangan penggerek buah kakao

senyawa penolak (antisenosis) dan aatau bersifat antibiosis bagi serangga. Kandungan senyawa tanin dalam tanaman dapat berpengaruh negatif terhadap biologi serangga seperti kematian mendadak maupun perlahan-lahan selama pertumbuhan dan perkembangan serangga (Smith, 1989). Kematian mendadak terjadi pada fase telur dan larva muda, sedangkan kematian perlahan terjadi pada fase larva tua, prapupa, pupa, dan imago, dengan demikian dapat berpengaruh langsung terhadap kemampuan hidup individu serangga yang terlihat pada penurunan bobot, ukuran tubuh, dan laju pertumbuhan pradewasa serta kepiridian dan lama hidup imago (Kogan, 1986).

Faktor lain yang mungkin menyebabkan rendahnya persentase serangan pada buah yang berdiameter 3,5-4,5 cm adalah tingginya populasi semut hitam bersimbiosis dengan kutu putih. Buah dengan diameter 3,5-4,5 cm merupakan relung yang baik bagi kehidupan semut hitam dan kutu putih, baik pada buah kakao berwarna merah maupun hijau. Kutu putih termasuk golongan serangga tipe pencucuk dan pengisap. Pada buah yang berdiameter 3,5-4,5 cm memiliki alur buah yang dalam dan ketebalan kulit buah yang tipis, sehingga kutu putih lebih nyaman dan gampang menusukkan styletnya mengisap cairan buah dibandingkan pada buah yang lebih tua. Sulistyowati (2003) menyatakan bahwa kehidupan kutu putih saling tergantung dengan semut hitam. Semut hitam selalu hidup bersama atau bersimbiosis dengan kutu putih. Sekresi yang dikeluarkan oleh kutu putih mengandung embun madu yang dibutuhkan oleh semut hitam dan semut hitam sengaja atau tidak sengaja dapat membantu menyebarkan nimfa kutu putih. Semut hitam dapat berfungsi sebagai agen pengendali hayati jika populasinya di dalam ekosistem kakao cukup melimpah, untuk meningkatkan kelimpahan populasi semut hitam dapat dipancing dengan menyediakan sarang untuk keperluan berkembangbiak. Sarang dapat berupa lipatan-lipatan daun kelapa atau daun kakao yang disemprot larutan madu dan diletakkan dalam bambu berukuran panjang $45 \mathrm{~cm}$ dengan diameter 5-7 cm. Aktivitas semut hitam yang selalu berada di permukaan buah menyebabkan penggerek buah kakao terganggu melakukan pendaratan dan penusukkan ovipositornya untuk 
Ni Made: Pengaruh penyarungan dengan berbagai ketebalan plastik dan diameter buah terhadap serangan penggerek buah kakao

meletakkan telur pada buah kakao, sehingga buah terbebas dari serangan penggerek buah kakao.

Persentase buah terserang penggerek buah kakao pada diameter buah 3,5-4,5 cm paling rendah, baik pada buah kakao berwarna merah maupun hijau. Rendahnya buah terserang pada buah diameter 3,5-4,5 $\mathrm{cm}$ terkait dengan umur buah. Buah-buah muda kurang disukai penggerek buah kakao karena tingginya kandungan tanin dan fenol dibandingkan buah yang lebih tua.

Persentase biji terserang pada buah tanpa sarung lebih tinggi dibandingkan dengan buah-buah yang disarung. Kejadian itu disebabkan oleh adanya penghalang fisik berupa sarung plastik pada buah. Pada buah yang tidak disarung memudahkan penggerek buah kakao untuk menemukan dan menusukkan ovipositornya pada buah dibandingkan dengan buah yang disarung. Pada perlakuan penyarungan, persentase biji terserang penggerek buah kakao pada buah yang berdiameter $>6,0-7,5 \mathrm{~cm}$ paling tinggi dibandingkan buah yang lainnya. Peristiwa itu kemungkinan terjadi karena imago penggerek buah kakao telah mengalami perubahan perilaku bertelur. Kemungkinan PBK di tempat penelitian telah resisten terhadap sarung plastik dengan melakukan penginderaan terlebih dulu sebelum meletakkan telur. Pada buah yang tersarung telur tidak diletakkan di permukaan plastik, tetapi imago mencari kulit buah dulu melalui ujung plastik yang memang terbujka, setelah dirasakan tekstur kulit buah baru dia meletakan telur, untuk itu perlu dilakukan pengkajian lebih lanjut.

Persentase biji terserang penggerek buah kakao menyebabkan kualitas dan kuantitas biji menurun sehingga persentase kehilangan hasil menjadi lebih besar. Perlakuan penyarungan dapat menekan penurunan kualitas dan kuantitas produksi biji, baik pada buah berwarna merah maupun hijau. Perlakuan penyarungan pada buah yang berdiameter 3,5-4,5 $\mathrm{cm}$ persentase kehilangan hasil dapat dittekan sebesar $96,08 \%$ pada buah merah dan 96,69\% pada buah hijau, sedangkan pada buah yang berdiameter $>4,5-6,0 \mathrm{~cm}$ persentase kehilangan hasil dapat ditekan hingga $83,30 \%$ pada buah merah dan $91,37 \%$ pada buah hijau. Pada buah dengan diameter $>6,0-7,5 \mathrm{~cm}$ hasil yang dapat diselamatkan sebesar $62,88 \%$ 
Ni Made: Pengaruh penyarungan dengan berbagai ketebalan plastik dan diameter buah terhadap serangan penggerek buah kakao

dan $69,66 \%$ masing-masing pada buah merah dan hijau. Pada perlakuan tanpa penyarungan kehilangan hasil pada buah yang berdiameter $3,5-4,5 \mathrm{~cm}$ mencapai $39,89 \%$ pada buah yang berwarna merah dan $33,49 \%$ pada buah hijau. Pada buah dengan diameter $>4,5-6,0 \mathrm{~cm}$ kehilangan hasil mencapai $43,47 \%$ pada buah merah dan 48,27\% pada buah hijau, sedangkan pada buah diameter $>6,0-7,5$ cm kehilangan hasil mencapai $36,00 \%$ pada buah merah dan $40,48 \%$ pada buah hijau. Hasil penelitian ini memperkuat pendapat Wardojo (1981) dan Sulistyowati (2003).

Penyarungan pada buah yang berdiameter 3,5-4,5 cm tampak efektif menurunkan serangan penggerek buah kakao, tetapi agak rentan terhadap serangan penyakit busuk buah kakao terutama dengan ketebalan plastik 0,02 mm pada buah kakao berwarna hijau. Kejadian itu mungkin disebabkan oleh factor kelembaban lingkungan. Pada buah hijau sumber inokulumnya lebih banyak, sehingga dengan adanya efek penyarungan akan menyebabkan kondisi buah menjadi lebih lembab sehingga memudahkan patogan menginfeksinya, sedangkan pada buah merah kemungkinan sumber inokulumnya lebih sedikit sehingga serangan penyakit busuk buah lebih rendah, disamping adanya perbedaan tekstur kulit buah antara kakao merah dan hijau.

Penyarungan dengan berbagai ketebalan plastik dan diameter buah berpengaruh nyata terhadap infeksi penyakit busuk buah kakao. Buah yang tidak disarung mendapat serangan lebih berat dibandingkan buah yang disarung, kecuali buah yang disarung dengan plastik yang tebalnya $0,02 \mathrm{~mm}\left(\mathrm{~S}_{1}\right)$, baik pada buah merah maupun hijau. Kejadian itu mungkin disebabkan oleh faktor lingkungan. Pada buah yang tidak disarung apabila kondisi lingkungan mendukung perkembangan spora, akan memberi peluang yang lebih besar untuk diserang penyakit busuk buah kakao dibandingkan dengan buah yang disarung, sedangkan plastik yang tipis mudah menempel pada keseluruhan permukaan buah, sehingga uap air yang timbul dalam buah memungkinan kondisi baik bagi perkecambahan spora yang masuk kedalam sarung. Kondisi itu diduga memicu proses inkubasi jamur yang menular kedalam buah sehingga 
Ni Made: Pengaruh penyarungan dengan berbagai ketebalan plastik dan diameter buah terhadap serangan penggerek buah kakao

menimbulkan penyakit busuk buah pada buah kakao.

Penyarungan dengan ketebalan plastik sarung $>0,02 \mathrm{~mm}$ dapat menekan serangan dengan kehilangan hasil total yang lebih rendah dibandingkan dengan perlakuan $\mathrm{S}_{1}$. Belum diketahui dengan pasti penyebab keefektifan tersebut, namun dapat diduga bahwa ketebalan plastik tersebut relatif keras sehingga tidak menempel pada buah saat buah basah sewaktu diterpa air hujan. Kondisi seperti itu dapat mencegah infeksi penyakit busuk buah kakao. Ketebalan plastik tersebut juga tidak berpengaruh buruk terhadap kehidupan semut hitam yang bersimbiosis dengan kutu putih dalam mencegah imago penggerek buah kakao dalam peletakan telur.

Pemanfaatan plastik sarung yang tebalnya >0,02 mm tampak efektif melindungi buah dari serangan penyakit busuk buah kakao terutama pada buah yang berdiameter $>4,5-6,0 \mathrm{~cm}$. Kesesuaian plastik sarung tersebut juga tampak menekan serangan dengan kehilangan hasil total yang lebih rendah dibandingkan dengan perlakuan $S_{1}$. Berdasarkan fakta tersebut, maka penyarungan buah dengan plastik yang tebalnya $>0,02 \mathrm{~mm}$ pada buah yang berdiameter $>4,5-6,0 \mathrm{~cm}$ efektif mencegah serangan penggerek buah kakao dan penyakit busuk buah kakao sehingga penurunan kualitas dan kuantitas hasil dapat ditekan.

\section{SIMPULAN}

1. Berdasarkan persentase buah terserang, penggerek buah kakao lebih menyukai buah yang berdiameter $>4,5-7,5 \mathrm{~cm}$, baik pada buah kakao berwarna merah maupun hijau.

2. Sifat biofisik buah yang berpengaruh terhadap preferensi penggerek buah kakao adalah alur buah yang dalam dengan kulit buah yang tipis, sedangkan kandungan biokimianya meliputi senyawa nutrisi (protein, gula) tinggi dan senyawa non nutrisi (tanin, fenol) rendah.

3. Persentase buah terserang penggerek buah kakao paling rendah pada buah yang berdiameter 3,5-4,5 cm, sedangkan persentase biji terserang paling tinggi pada buah yang berdiameter $>6,0-7,5 \mathrm{~cm}$, baik pada buah yang berwarna merah maupun hijau. Perlakuan penyarungan mampu menekan persentase 
Ni Made: Pengaruh penyarungan dengan berbagai ketebalan plastik dan diameter buah terhadap serangan penggerek buah kakao

kehilangan hasil. Persentase kehilangan hasil pada buah dengan diameter 3,5-4,5 $\mathrm{cm}$ dapat ditekan sebesar $96,08 \%$ pada buah merah dan 96,69\% pada buah hijau, sedangkan pada buah yang berdiameter > 4,5$6,0 \mathrm{~cm}$ persentase kehilangan hasil dapat ditekan hingga $83,30 \%$ pada buah merah dan $91,37 \%$ pada buah hijau. Pada buah dengan diameter > 6,0-7,5 cm hasil yang dapat diselamatkan sebesar $62,88 \%$ dan $69,66 \%$ masing-masing pada buah merah dan hijau.

4. Ketebalan plastik > 0,02 $\mathrm{mm}$ yang dipasang pada buah berdiameter > 4,5-6,0 cm tampak efektif menurunkan serangan penyakit busuk buah kakao.

5. Penyarungan buah kakao dengan berbagai ketebalan plastik dan diameter buah tidak berpengaruh buruk terhadap kehidupan semut hitam yang bersimbiose dengan kutu putih untuk mencegah peletakan telur imago penggerek buah kakao pada buah.

\section{Ucapan Terima Kasih}

Pada kesempatan ini penulis ingin mengucapkan terima kasih kepada semua pihak yang telah membantu dengan caranya masing-masing dalam melengkapi tulisan ini.

\section{DAFTAR PUSTAKA}

Azhar, I. 1992. Role of Black Ant in Cocoa Natural Control. MAAPSNewsletter. 16(4) : 36-37

Dinas Perkebunan Provinsi Bali. 2007. Statistik Perkebunan Bali 2007. Statistical Estate Crops of Bali 2007. Denpasar : Pemerintah Provinsi Bali Gomez, K.A.,A.A.1995. Prosedur Statistik untuk Penelitian Pertanian. Diterjemahkan oleh Syamsuddin, E., Baharsyah, J.S. Jakarta : Universitas Indonesia. 698 hal

Oka, I.N.1995. Pengendalian Hama Terpadu dan Implementasinya di Indonesia. Yogyakarta : Gajah Mada University Press. 255 hal

Siregar, T.H.S.,Ryadi, S.,Nuraeni,L.1994.

.Jakarta : Penebar aaswadaya. 170 hal Sulistyowaty, E. 2003. Pengenalan Hama Utama. Teknik Pengamatan dan Pengendalian pada Tanaman Kakao. Jember : Puslitkoka

Suparno, T. 2001. Investasi Penggerek Buah Kakao di Perkebunan Kakao Kawasan Kerkap, Bengkulu Utara dan Pengendaliannya. J. Hama dan 
Ni Made: Pengaruh penyarungan dengan berbagai ketebalan plastik dan diameter buah terhadap serangan penggerek buah kakao

Penyakit Tumbuhan Tropika. 1(1) : $11-14$

Supartha, I. W. 2007. Pengendalian

Hama Penggerek dan Penyakit

Busuk Buah Kakao dengan Pola

Integrasi. Makalah seminar dalam rangka Dies Natalis Universitas Udayana yang diselenggarakan oleh jurusan HPT Fakultas Pertanian Unud di Gedung GDLN Unud. Denpasar-Bali 16 Januari 2007

Supartha, I. W. 2008. Pengendalian Hama Penggerek dan Penyakit Busuk Buah Kakao secara Integrasi. I M. Mastika dan I W. Susila (Editor). ISBN 978-979-18979-0-7. Penerbit : Dinas Perkebunan Provinsi Bali. 86 hal 